\title{
Security Challenges and the Imperatives of State Police
}

\author{
Eme, Okechukwu Innocent \\ Email: okechukwunncnt@yahoo.com \\ 08056753011 \\ Anyadike Nkechi $\mathbf{O}$. \\ Email: nkee4jesus@yahoo.com \\ Department of Public Administration and Local Government \\ University of Nigeria, Nsukka. \\ 08032680656
}

\begin{abstract}
Arguments for and against the establishment of State Police Force have been going on for quite some time now. Proponents of state police argued that this was a consistent with the principle of true federalism and decentralization of powers and that the arrangement would enable the states to effectively maintain law and order especially during emergencies. They criticized section 215(4) of the 1999 Constitution for hindering governors from the exercise of his power as Chief Security Officer of the state. Opponents of state police hinged their theses on the fear of the abuse to which State Governor may subject the police. The fears include those of harassment and intimidation of politics opponents and perpetration of electoral fraud. This paper seeks to explore the major imperatives for the establishment of State Police Force. To achieve this objective, the essay discusses the major theses the opponents and proponents of State Police Force, the limitations of their arguments. It however agrees that there is to need for reorientation; reorganization and repositioning of the Nigeria Police Force to enable it meet the requirements of public order, public safety and democratic governance.
\end{abstract}

Key word: Police, Vigilante Groups, Insecurity Violent Crime, Democratic Governance, Policing and True Federalism

\section{Introduction}

It is a truism that the recent phenomenal wave of political assassination, murders, armed banditry, kidnapping and general eruption of insecurity in Nigeria has put both the government and the populace on the edge. There is hardly a day that passes without sorry tales of pre-meditated killings, armed robbery and other crimes and attacks nationwide. 
In the last few months, some prominent politicians and business moguls have been attacked, killed or robbed in unresolved circumstances. The intriguing aspects of these fatal developments is that the president, Musa Yar'Adua and his predecessor, in most cases authoritatively declared and lay blame on the Nigerian wobble economy, and antidemocratic forces.

What these contending perspectives suggest is that the government has not shown any seriousness towards the issue of safety of life and property in Nigeria until the invasion of top political, business brass and appointees by the criminals. This underscores the haphazard response to the assaults and contradictory explanations coming from different government quarters pertaining to waves of attacks.

These political tensions are compounded by the reality that Nigeria's economy has grown since 1999, and yet this wealth has been neither seen nor felt by the last majority of Nigerians. Nearly three-quarters of the populace live on less than one dollar a day in a country that has earned oil revenues if at least USD 280 billion over three decades, excluding the past few years of high oil prices (Eme, 2009:2). Ethnic tensions, religious differences, limited economic opportunities, and numerous socio-political grievances are all fuelling the unrest in Nigeria and contributing to flashpoints for violence.

In all the reactions so far, government has not even addressed the fundamental and immediate causes of these manifestations. All that have dominated former Obasanjo's and Yar'Adua's and Jonathan's security question policy have been redeployment of police top brass and other security personnels without any attentions to the questions of political intolerance, unemployment, escalating impoverishment and the population's despondency, all of which have made ordinary Nigerian, unbearable.

Nigeria projects an image of politics that is nasty, brutish, and bestial. In short, Nigeria and her leadership has dishonoured her past and 
fashioned a present that premises no future except more pains and shame and even more precarious existence.

As a result of the above, analysts have variously described the Nigerian State as predatory, propaganda tilled, parasitic, patrimonial, decadent, criminalized, chronic, venal, irrational, cleptocratic and impotent. This image has been so powerful that even those who have risen top in her defense have been deeply influenced by it.

The Nigerian militant group Boko Haram conducted a series of bombing attacks and armed assaults January 20 in the northern city of Kano, the capital of Kano State and second-largest city in Nigeria. The attacks, which reportedly included the employment of at least two suicide vehicle-born improvised explosive devices (VBIEDs), targeted a series of police facilities in Kano. These included the regional police headquarters, which directs police operations in Kano, Kastina and Jigawa States, as well as the State Security Service office and the Nigerian Immigration Service office. At least 211 people died in the Kano attacks, according to media reports. The group carried out a second wave of attacks in Bauchi State on January 22, bombing two unoccupied churches in the Bauchi metropolitan area and attacking a police station in the Tafawa Balewa local government area. Militants reportedly also tried to rob a bank in Tafawa Balewa the same day. Though security forces thwarted the robbery attempt, 10 people reportedly died in the clash, including two soldiers and a deputy police superintendent. In a third attach, Boko Haram militants attached a police sub-station in Kano on January 24 with small arms and improved hand grenades. A tally of reportedly lasted some 25 minutes, was not available. This armed assault stands out tactically from the January 20 suicide attacks against police stations in Kano. The operation could have been an attempt to liberate some of the Boko Haram militants the government arrested following the January 20 and January 22 attacks. Stratford has followed Boko Haram carefully to assess its intent and ability to become more transnational. As we noted after the U.S State Department issued warning in early November 2011 about Boko Haram's alleged plans to strike Western-owned hotels in Abuja, Nigeria's capital, the group made significant leaps in its operational 
capability during 2011. During that time, it transitioned form very simple attacks to successfully employing suicide VBIEDS. An examination of the recent attacks in Kano and Bauchi States, however, odes not reveal further advances in the group's operational tradecraft and does not display any new ability or intent to project power beyond its traditional areas of operation.

Now members of the National Youth Service Corps (NYSC) are rejecting postings to troubled spots with justification. On daily basis, there are cries of dependency and government appears to be helpless.

Can the federal government restore security? What is responsible for all the sporadic bombings? Why has Jos remained a troubled spot? These are puzzles that seem to have no answers.

Just recently, governors were at a crossroads. Although, it is the north that is primarily under siege, southern governors could not turn their eyes away from the plight of their kinsmen who reside in these troubled spots. The Nigeria Governors Forum (NGE) proposed some measures. Taking a global look at the socio economic and political realities that may underlie insecurity, it suggested a sort of 'Marshal Plan' to tackle the land. Some governors also reiterated their clamour for state police.

Ekiti State Governor Kayode Fayemi, who spoke briefly with reporters in Abuja, Said that police was long overdue. He highlighted the numerous assistants given to state police commands by governors, including donation of vehicles, uniforms housing, guns, and even, bullets. He said it is illogical that the state governors, who are chief security officers, have no control over the police.

Many reasons have been adduced for the state of insecurity ravaging the country. Some of them paled into conjunctures. But there is no evidence that government has got any lead as well. There is a monotony of assurances of normalcy from the Police Inspector General of Police (IGP), Mohammad Abubakar and Chief Defence Staff Air Vice Marhall Olu Pettinrin. To their consternation, the suicide bombers seem to have dwarfed security agents. 
There have been rumours that the north is aggrieved that the Presidency has stayed too long in the South contrary to agreement. Recently, former Security Adviser Gen. Patrick Aziza attributed the Security problem to the People Democratic Party's (PDP) Zoning arrangement, which was jettisoned during the last presidential election. His remark caused a stir. Few Weeks after he was shoved aside.

Others have argued that it was part of a clandestine plan by the Boko Haram sect to wipe out non-natives and adherents and other faiths. Taking exception to this, foremost commentator, Mallam Mohammed Haruna corrected the erroneous impression that the Boko Haram sect was waging a religious war against Christians alone, adding that Muslims are more causalities. He said the violence unleashed by the group has created strains on the economy of Northern Nigeria, emphasizing that Boko Haram is a threat to all Nigerians.

He lamented that the media has been subjective in their reports of the conflict, complaining that reports were laced with anti-northern sentiment. Haruna also pointed out that the fear of Bomo Haram has made government to violate the rights of some Nigerians under the guise that they are suspects. The affected citizens, he said, are languishing in jail.

The Chairman of Nigerian Guild of Editors, Mr. Gbenga Adefaye, urged reporters to avoid labeling and sentiments. If these are avoided, he counseled, misinformation would be avoided and tension reduced to the bearest minimum.

An expert on security, Col. Gabriel Ajayi, who reflected on the security challenges facing the country at a recent birthday lecture in honour of Prof. Wole Soyinka in Lagos, berated the lip service being paid to security right from colonial days. He argued that security projections were limited to securing those in power, while the citizens are left in the wilderness of hope and despair. He added that since then, Nigeria has failed to develop a security system to sustain its socio-economic and political development. 
Ajayi, who covered the Agbekoya uprising as a reporter in 1969, lamented that, under the indigenous rulers, security was also tackled with aloofness and treated as a no go area. Even, Prime Minister Tafawa Balewa deliberately ignored warnings that a coup was about to depose or kill him.

Military came and put up security system for tenure survival. It was the climax of the 'Glover Syndrome' of using the people to keep the people under bondage.

Ajayi could not properly dissect the dreadful sect, Boko Haram. But the he acknowledged that the insurgency resembled a campaign of unidentified people who cannot be properly traced, a people who treat everywhere as no man's land. The retired soldier compared deaths resulting from Boko Haram activities to the ones attributed to the carnage on bad roads, resulting from what he called siege on the people by government.

In view of the above contending theses, this paper seeks to address the imperative of state police as a solution to security challenges in Nigeria. To achieve this objective, the first section of the paper examines conceptual issues. The next part argues for and against for state police. The third section discusses the imperative of state police. The final offers recommendations and concludes the paper.

\section{Clarification of Concept}

Security generally is a crosscutting, and multi-dimensional concept which has, over the last century, been the subject of great debate. However, long before that, the history of mankind was interspersed by the frenzied search for the best way of ensuring the security of people, their property, their territories, their states and their institute among others. In all places and countries, security has been considered as a "first order value" worth preserving. The foreign withstanding, there is no consensus about or agreed general definition of security. This is not surprising because as a social phenomenon, it is always the case which hardly lends itself to common understanding because it is often approached from different perspectives. 
Some security experts argued that the concept of security ha s always been associated with the safety and survival of the state and its citizens from harm or destruction or from dangerous threats. For some other, security measures the absence of treats to acquire values in a subjective sense, the absence of fear that such values will be attached. Thus a nation is secure to the extent to which it is not in danger of having to sacrifice core values if it wishes to avoid war, and is able, if challenged, to maintain them by victory in such a war (Maulaye, 2006: 17-18). Those conceptions generally hold that the state is the only institution on which primary responsibility and power for the safety of its territory and its people reposes (Zabadi, 2005:3). Therefore for some others, security consists of a functional and interdependent body of supervisory services and institutions.

Security is also a situation wherein a person or thing is not exposed to any form of danger or risk of physical or moral aggression, accident, theft or deterioration. Both security and peace are together.

The concept of "national security" is often misunderstood (Wolfer, 1962) and elusive (Carey, 2000). It is a strange phenomenon, a subjective "felling", and therefore relational and relatives, rather than an objective "thing" than can be seen and handled. You cannot touch security - you can only feel secure.

If security is something that can only be felt, it must be security from something (a threat of one sort or another). For the state, the most obvious threat is that posed by another state (a threat of invasion of control by another power leading to loss of independence). This is in a manifest in a military threat, or very significantly, in the perception of a threat. This offers an explanation of the fact that in the era of the cold war Great Britain did not feel threatened by the Russia.

National security defined in terms of national survival is an illusion. It is an illusion because it is an erroneous perception of the African reality. It is used by the milling elite as a fine transparent concept for deluding the populace into thinking that government policies in this regard represent actions designed actually to protect them from hunger, 
disease, injustice, and violation of human dignity and life. Thus, in Nigeria the concept "national security has given rise to two dangerous doctrines of illusionism and militarism which is self-defeating.

However, scholars are yet to agree on the definition of the term "national security". This is not surprising because, the phenomenon of security is hardly precise. Yet two fundamental perspectives have emerged in the attempt to defend national security. One perspective focuses on strategic definition and the other, on the non-strategic definition by laying emphasis on socio-economic factors. The strategic -"realist" perspective conceptualizes national security in terms of selfdefense by amassing arms to deter aggression. This perspective sees conflict between men and states as being endemic. To a great or lesser degree, therefore, the international political system can be seen as anarchic, power and the struggle for power and the control of resources is central to this manner of thinking. In this environment, states will only be constrained by pacts, audiences, treaties and tenets of international law that they see as being in their own interests. Security in this context concentrates in the military, military values, strategies and capabilities and the survival of the state.

If security is focused on the survival of the state, then logically security has first call of the resources of the state. It is very noticeable that the first act of newly independent states is to create an armed force and that even in the poorest of states the military are well equipped and enjoy a high status in society. In this situation, to have a problem or issue labeled a "security issue" ensures that there is a flow of resources to solve the perceived threat or problem. Astute politicians, therefore, begin to promote essentially non-security issues as being matters of high security significance (Carey, 2000:57). According to Rourke and Boyer (2003):

From 1948 through 2002, for example, the world states spent about 1,300 times as much on their national military budgets (about \$38 trillion) as on UN peacekeeping operations (about \$29 billion). It just may be, then, the first secretary-general of the United Nations, Trygue lie was onto something when he suggested, "wars occur because people prepare for conflict, rather than for peace. 
The responsibility of the state to provide security for itself and its citizens allows the state to impose all manner of draconian measures on society (e.g. Conscription, Official Secret Acts). In defending the state, the state itself assures major power itself, including the possibility of reorganizing socio-economic fabrics if society, as happened in both the First and Second world wars. In time of overt conflict, the whole of domestic society and politics are dominated by the single issue of security. The military is the agency of the state designed to protect the people, its territory and their most cherished values from external attack. The military is, therefore, created and organized in such a way to provide this protection. Soldiers are trained to kill and be killed in pursuit of the national interest. In the absence of external enemies, the Soldiers have turned their deadly skills against their compatriots. As Nnoli (2006:10) posits:

One of the problems with these re-conceptualizations of national security is that they have not also re-conceptualized the military to conform to the new forms of security. Instead, the concept of peacekeeping is merely accreted to the orthodox concept of military. In Africa, this is not useful. The military, under the control of political leaders, still kill the people before a peacekeeping force is sent in from outside the country. Democracy has remained elusive. Vested interested in the present concept of the military on the part of both the military and the government, and the major powers whose national interests are significantly external in nature and who influence what concept prevail in the world community, have ensured that no fundamental changes have been advocated in the nature and functions of the military. Rigid and old thinking on the nature and functions of the military has produced the same effect.

In general, Braithwaite (1988:9) quoting the encyclopedia of the social sciences defines national security as "ability of a nation to protect its internal values from external threat". Also, Lipmann defines it by stating that "a nation has security when it does not have to sacrifice its legitimate interest to avoid war, and is able, if challenged, to maintain them by war". Morgenthau (1948) posits that national security and national interests are inter-related; where the former are seen in terms of 
power and therefore are the essence of politics. Imobigbe (1981) refers to it as the defense and survival of the state. The danger of looking at national security from this narrow angle according to Nweke (1988:1-2) is three-fold:

First is the tendency to equate "defense" with "security" and to bestow undue responsibilities to the military as if the armed forces alone are the guardians of national security. This tendency in turn creates in the minds of the armed forces that it is only through them that security, stability and progress can be achieved. Second, national security has been used by civilian statesmen as political rhetorics or slogan for rallying the citizens in the face of perceived internal or external threats to the governments in power and for bolstering their local influence and political base (Adebayo, 1986:23).

Late President Yar' Adua told a joint session of the National Assembly before which we placed the 2008 Appropriation Bill:

We intend to enhance the capacity and preparedness of our security services. We have therefore, proposed a total allocation of $\$ 444$ billion (about 20\%) for the military and the police. We are providing our security services with all requisite force enablers and multipliers, including arms and ammunitions, improved information and telecommunication equipment and facilities, riot control equipment, training and retraining and sundry logistics support (Oluwasegun and Anofi, 2007:2).

The most serious danger is the tendency to equate national security with the security of the state. The state in a capitalist state like Nigeria is an instrument for the preservation of capitalist socio-economic formation, which protects the interests of a privileged class vis-à-vis the rest of us (Ake 1984, 302).

Dyke (1966), concludes as follows: There is no doubt that national security embodies the sovereignty of the state, the inviolability of its territorial boundaries, and the right to individual and collective selfdefense against internal and external threats. But the state is secure only 
when the aggregate of people organized under it has a consciousness of belonging to a common sovereign political community; enjoy equal political freedom, human rights, economic opportunities, and when the state itself is able to ensure independence in its development and foreign policy.

The non-strategic thesis thinks anew about security from armed aggression in the light of humankind's failed effort to find it. This is because the strategic path has not brought us to a consistently secure place, it is only prudent to consider alternative, less - or avelled paths to security. These possible thesis including limiting or even abandoning our weapons altogether, creating international security force and standards of pacifism. According to Nnoli (2006:VII):

... a new concept of national security follows with a congruent new form of the military. National interest in Africa is defined as the creation and promotion of democracy, which goes beyond elections to policymaking and implementation through dialogue, reconciliation and consensus building. In order to defend this national security, the military must be organized along the lines of the principles of peacekeeping. It must be a military that is driven by the desire to emphasize early warning of violent conflict, separating the conflicting parties, reconciliation of these parties, the mediation of their disputes, and solution of their post-conflict relations and problems....

According to Al-Mashat (1985:14), national security is more than territorial defense and should focus on "the physical, social and psychological quality of life of a society and its members, both in the domestic setting and within the larger regional and global system", Braithwaite (1988:9) adds: "it is submitted, therefore, that in the final analysis, the domestic, socio-economic and political environment of a sovereign state is the all-important and critical factor in national security considerations. Put succinctly, national security is positively correlated with the increase in the distributive capability and genuine democratization of a given state". That is, "the tranquility and wellbeing of a society are pre-conditions for security" (Al-Mashat, 1985:XI). By well-being, I mean, the ability of the democratic state to provide its public with social, economic, and political conditions conducive to happiness and relative prosperity, which are some of the 
basic elements of national security. It is clear today that, the concentration of national security question on its strategic-military perspective alone breeds tension and resentment, leading to violent conflicts and civil wars and military coups, counter coups and state sponsored terrorism all over Africa.

Consequent upon the above theses in the definition of national security, there is a contention between national security and individual freedom. Therefore the problem of national security, its definition or analysis is fundamentally, about, how much of individual freedom should be sacrificed for national security and how much power is required to maintain the proper balance between order and fundamental human rights and civil liberties. In order words, in Africa, the conceptualization of national security in terms of external attack is largely irrelevant. It must be viewed from the point of view of democracy, how to create and consolidate democracy in Africa. In fact, there is general acceptance that national security must go beyond the narrow focus on external attack and the use of military to defeat it. Hence, one hears of human security, global security, environmental security and various other forms of security, which require other than the military to attain.

The main intellectual challenge to the accepted view of security came well before the formal end of the cold war. Buzan (1993) was a clear intellectual challenge but more subtly it exposed the limits of the strategic-military-traditional new of security and extended the debate about the nature of security. He added to the military aspects of security, the political, economic, societal and ecological aspects. In another respect he did not broaden, concentrating on the state as the main agency which can deliver security, although in doing so it was a necessary to work at what was happening within states and also at the systematic level. On this basis those military matters which had once dominated security studies were best thought of as only one part, which Buzan (1987) assigned to strategic studies (Freedman, 2003:258). Freedman (1998:53) view is that:

Once anything that generates anxiety or threatens the quality of life in some respect becomes labeled as a "security problem" the field risks 
losing all focus. Such an agenda as potentially rich, and is certainly inclusive, but it can also be off-puttingly vague. Inappropriate conclusions are likely to be reached of issues that are quite different in kind are squeezed into an unsuitable conceptual framework geared to military threats. The notion of economic security thus encourages a confrontational approach to trace policy, while that of "environmental security" has often served more to confuse than to clarify by encouraging a search for adversaries.

Waever (1995) captures this sort of problem through this helpful notion of "securitization", which addresses the interesting question as to why some issues rather than others are considered to be problems of security. His point is that when issues are assigned this status they acquire extra significance, which can legitimize the mobilization of resources and the adoption of urgent and extra ordinary measures. He therefore, along with Buzan (1993), that the key question is what issues become "securitized" and how this takes place, and under what conditions can be "de-securitized". Each of the political, economical, societal and ecological aspects identified 'earlier by Buzan (1993) can then be considered in these terms. This provides a basis for explaining why the issue of "environmental security", for example, has emerged but also why it is important to challenge this designation (Freedman, 2003:7589).

Freedman (2003:760) concludes: Nor does a focus on force require neglect of the economic, social and political dimensions. These all shape security environments, helps defend what is to be defended and the factors which might generate threats. To make sense of Iraqi's occupation of Kuwait in 1990 the importance of indebtedness and declining oil price must be understood. Oil helps explain - in partRussia's effort to hold on to Chechnya. Environmental abuse, the drug trade and people trafficking can all aggravate tension between states and create powerful grievances in a population. Violence in the Balkans has been influenced at every turn by cultural factors. The restriction comes in resisting attempts to distinguish security issues in these dimensions separate from those connected to armed force. It is unlikely that a conceptual framework devised with armed force in mind will suit these 
other dimensions, and if separate frameworks are required then there can be one.

However, contemporary definition of security, especially since the fall of the Berlin wall goes beyond the traditional context. It embraces new domains as varied as individual security, collective security and social, political, economic, legal judicial, financial, food, health, environmental ad other aspects of security. It has even added a philosophical dimension, as Baron Montesquieu says: "security is tranquility of mind stemming from each one's idea of his personal safety" (cited in Moulaye, 2006:19)

\section{State Police: The Contending Theses}

In the face of the deploring security situation confronting the nation at this time, some proponent of a state police believe that it is only a decentralisation of the force as practiced in most developed countries can rescue the nation from the precipice. Doing so, they maintain, will give room for the central command to focus on raising a crop of highly professional crop of central squad that may be deployed from time to time when the need arises. At present, the police strength is put at about 371,800 as against a population of 150 million Nigerians. Judged by the United Nations Standard, the number of available policemen is grossly inadequate as it does not meet the 400 to 1 ratio requirement. With a state police structure, the federating units would be able to determine their security needs and raise enough manpower to meet them (Eme,et.al,2009:15).

Beside, each state has its own peculiar security challenges which can only be better managed by the officers who are familiar with the terrain, culture and way of life of a particular people in a given locality.

While for, instance, the trend of violence and criminally ongoing in the northern region bother essentially on religions fundamentalism, the South-East and South-South regions have always grappled with kidnapping, armed robbery, youth militancy and vandalism as their own peculiar security situation. Within the Southwest Region, especially Metropolitan Lagos, area boys syndrome and hooliganism have 
remained a unique future of the environment. It is, therefore, believed that only a decentralized police structure where people who hail from an area and are familiar with the terrain and the criminals in the neighborhood are entrusted with responsibility of policing that can carry out effective contain crime and criminality. In developed nations, the police are trained according to the peculiarities of the localities in which they operate.

Nevertheless, those on the other side of the fence are often too quick to puncture this argument. In the opinion of some stakeholders, creating state police at this stage of the present democratic experiment may be an invitation to chaos. Apart from the impunity of office and the possibility of abuse of power, state police could lead to the disintegration of the country, especially now with the fragile unity in the country.

In the pre-independence era, the Native Authorities were in direct control of their domains. It was the primary responsibility of the NA police to maintain law and order ion their respective localities. Through the NA police departments, the naïve authorities were able to enforce local ordinances, byelaws, rules and regulations of the localities or municipalities over which they presided. It was the intervention of the military in the nation's body politics that foisted a centralized police force on the entire country under the present quasi-unitary system of government.

Regardless of the pros and cons of the debates, creation of a State Police structure would also be a major leap in the nation's match towards the much cherished true federalism that has eluded the nation for a long time.

It is sine-qua non to genuine principles of true federalism. In the immediate post independent era when regional government was in direct control of its affairs, each region has its own police structure independent of the power at the centre. However, history has it that some regional political leaders abused local policing as the local police force was used as instrument of political intimidations and harassments against their opponents. Even now, the tendency is still very high for 
some over ambitious political leaders to turn state police to an instrument of apolitical vendetta. The immediate past experience in Anambra State where a sitting governor, Dr. Chris Ngige, was abducted in the broad day light through the connivance of the police is a good case in point. But the answer is neither here nor there. So, unless there is a proper reform and adequate checks and balances, state police can equally become a willing tool in the hands of the politicians, especially the overbearing ones.

A former Minister of Police Affairs and Governor of the old Oyo State, Gen David Jemibewon, has however suggested creation of Zonal police command as a way of forestalling abuse of power by the state governor. In an interview with Sunday sun, he said, "my view is that there should be state police"().

However, because there are 36 states now and if every state is to have state police, it means that there will be 37 police forces in Nigeria. That may be unwieldy. The $37^{\text {th }}$ will be federal police. Therefore, what Jemibewon advocated now is zonal police command. This is more so now that we have six geo-political zones in the country. And in doing so, we must ensure that the police officers in each zone are people who are domiciled there. For instance, if you have western police command, it must be made up of people who are residents in the western zone of the country. The same thing in the Easter zone, it must be people who are resident there what is simply means that there will still be federal police in addition to six zonal command. If anything happens, for example, the Northwest and the situation is so bad that you have to bring some policemen from other places, they will just decide which zone should contribute to that zone to deal with the situation. Under the arrangement, we may, however, have a single inspector General of Police and Deputy Inspector General in each geo-political zone.

Pro state police proponents support their theses using United State' State police as a case in point.

In all the 50 State of the United States, there are individual state police that enforce state laws and rules and regulations without much 
interference from the federal law enforcements, except in a special circumstance like September 11, 2003 attack on Pentagon House World Trade Centre where the US Federal Government may want to exercise some supremacy. The state police have statewide authority to conduct law enforcement activities and criminal investigations.

Hawaii is the only state that does not have a specifically named state police/highway patrol force. The functions of state-wide law enforcement are instead undertaken by the Sheriff Division of the Hawaii Department of Public Safety.

In General, state police perform functions outside the jurisdiction of the country Sheriff (Vermont being a notable exception), such a enforcing traffic laws on the highways and infer estate expressways, overseeing the security of the state capitol complex, protecting the governor, training new officers for local police forces too small to operate an academy, providing technological and scientific support services, and helping to coordinate multi-jurisdictional task force activity in serious or complicated cases in those states that grant full police powers statewide. In many states, the state police are known by different names. However, most have the same jurisdiction over the entire state as the agencies that are simply called "state Police". The rankings of the highway patrol may be trooper or officer. The names are usually historical and do not necessarily describe the agency's function or jurisdiction.

These forces are fully empowered law enforcement agencies with statewide jurisdiction, which conduct patrols and respond to calls for service and perform all the other aforementioned duties. The State Police may be the name of the independent agency or may fall under a Department of Public Safety. These states are Arkansas, Connecticut, Delaware, Idaho, Illinois, Indiana, Kentucky, Louisiana, Maine, Maryland, Massachusetts, Michigan, New Hampshire, New Jersey, New Mexico, New York, Oregon, Pennsylvania, Rhode Island, Vermont, Virginia, and West Virginia. 
Creation of state police is seen as a step towards actualizing the sustained campaign for community policing community policing is a philosophy that promotes organizational strategies, which support the systematic use of partnership and problem solving techniques, to proactively address the immediate conditions that give rise to public safety issues such as crime, social disorder, and fear of crime. It embraces community partnerships and collaborative partnerships between the law enforcement agency and the individuals and organizations they serve to develop solutions to problems and increase trust in policing in Nigeria in the recent time. The idea is to bring stressing the need for community policing as a way of combating the myriads of security challenges currently facing the nation. Jemibewon introduced community policing to the Nigeria Police. Community policing is more than the Nigeria police. Community policing is more than the impression you are trying to create now by saying that people should give them information. Community policing actually involves a process by which people can ascertain which police officers is assigned to a particular area.

We should be able to know who his is and too should be able to know by name the head of every family or household. And he should be involved in almost all their social activities. He is seen as part of that society. In that manner, if a visitor comes in, under 24 hours, he will know that this is a stranger. He virtually will know everybody such that even before a crime is committed, there are already people they will suspect because they would have known the pattern and character behaviour of everybody within the society.

Some stakeholders have described the call by the Governors' Forum for creation of state police and special intervention fund as self-serving. Many have even questioned the governors on how they spend security monthly security votes they get. Under the present arrangement, state governors are entitled to certain amount of allocation as security votes which are unaccounted for.

Obviously, a decentralized police structure will put additional financial responsibility on the states. And there is the fear in some quarters that 
the development may put some under funded state under undue pressure, if the responsibility of policing is put on there care. This explains the rational behind the governors demand for a special intervention fund to confront the security challenges facing the country. But the argument has been faulted because there has been no proper accountability on security votes accruing to the states.

\section{Recommendations}

Conflicts have multi-dimensional causes. Since Nigerians endorsed democracy in 1999, threats to civil rule should be averted. Nigerians believe that poverty, poor education and bad leadership were precursors to any crisis. The solution is good leadership. Other solutions include the marriage of native security and modern security to meet the needs of contemporary times. We need military operations, whereby, as we are welfare of people by providing roads, hospital employing force, we are also promoting the welfare of people by providing roads, hospitals, employment and other amenities.

The suggestions tallied with the advice given by a lawyer, Mr. Kola Awodein (SAN). At a lecture on true federalism and restructuring of the polity in Lagos, he said Nigeria should copy the policing methods of federal countries which are tailored towards community policing based on the police knowledge and understanding of the peculiar security needs of the local areas.

A journalist, Patrick Opoze, who aligned with this view, urged the government to uplift the current standard of policing. Policemen lack manpower, training and equipment and this should not be so (kajo, 2012:5).

Also, there is the for a one year compulsory military training or graduates , and a Sovereign National Conference (SNG), because, unless we have it, we cannot stand in brotherhood.

In fact, some security experts should send representatives to the conference to assist in stemming bombings. 
Insurgency and militancy and other forms of uprising of group protests against constituted authorities occur most of the time because peaceful and genuine aspirations of groups of people are disregarded over long periods. Armed rebellion does not occur over night anywhere in the world. Resort to violence is often times after peaceful protests and request have been ignored for unjustifiably long periods.

Speaking at a lecture titled. Roadmap to National Peace and Sustainable Democracy", organized by the Coalition of Ethnic Nationalities of Nigeria (CENN), Sabo, who was represented by Col Olu Majoyegbe (rtd), recalled that militancy in the Niger Delta was nipped in the bud, following the strategies intervention of the late President Umaru YarAdua's Administration. He lamented that the culture of respecting the views of ethnic blocs and groups propagating legitimate causes, have not have sustained in the country's.

He maintained that the best groups to articulate such group demands are those today derisively referred to as ethnic nationalities, adding that "government ought to as a matter of policy engage genuine ethnic national groups as effective partners in the arduous task of nationbuilding.

Sabo said, if this is done, the emergence of militants, insurgents and separatists would become unlikely with the high level of equity and justice such a policy would engender(Oderemi, 2012: 8 ).

Government working in synergy with ethnic nationality groups will create such an atmosphere of fairness, equity and commons destiny that would eliminating the security challenges, which may tear the nation apart in the future.

\section{Conclusion}

Since the beginning of the Nigeria's Fourth Republic, robbers, kidnappers, and other criminal gangs have intensified their activities. They are everywhere, on street, and highway, in our homes, and banks, party officers and campaign and voting centres. They rob, kill, and maim. All the security outfits do now is to bark without the ability to bite. 
The question most Nigerians ask everyday is: who will be the next victim? The security outfits whose constitutional duties and responsibilities is to control crime appear helpless. So many factors are said to be responsible for their inactivity. Among them are poor funding, lack of motivation and poor welfare services. They lack equipment and functional vehicles for their operation. Arms and ammunition are problems too. Faced with the upsurge of crimes, these security outfits are unable to perform. Some of the fallouts of this kind of situation include: social and political displacement and dislocation, social tensions, citizenship question, deepening of hunger and poverty in society and political insecurity and instability in the polity.

Achieving change in ways that policing is conducted in Nigeria will ultimately mean the basic protection of citizens. This requires improved security budgets, communication equipments, better training and orientation and constitutional and political restructuring. The introduction of state police will go a long way in meeting these demands.

\section{References}

Adebayo, A. (1986) Power in Politics. Ibadan: Spectrum Books.

Ake, C. (1984) “Parameters of Nigeria's Defense Policy" in M.Vogt and S.C. Ukpabi, National Interest, National Security and Defense Policy, Minne: Tradoc.

Al-Mashat, A.M. (1985) National Security in the Third World. Boulder; Colorado: Westview Press.

Braithwaithe, T. (1988) "foundations and Dynamics of National Security”, Nigerian Journal of International Affairs.

Buzan, B. (1983) People, States and Fear. Brighton: Wheat Sheef.

Buzan, B. (1987) An introduction to Strategic Studies: Military technology and International relations, London: Macmillan. 
Buzan, B. Waever, O. and Wilde, J. (1998) Security: A Framework for Analysis, Boulder: Lynne Rienner.

Carey, R. (2000), "The Contemporary Nature of Security", in Tevor C. Salom (Ed) Issues in International Relations. London and New York: Rout Ledge.

Dyke, V.V. (1966) Security and Sovereignty in International Politics. New York: Appleton-Century-Crofts.

Eme, O. I. (2004) "Insecurity Question in Nigeria: A Thematic Exposition," The Academy, Vol. 4, No. 4, (July) pp. 8-9.

Eme, O. I. (2009) "Ethno-Religious Identities in Nigeria: Implications for Good Governance in Nigeria." A Paper submitted to the Editor-in-Chief of a Book Project on Islam and Governance in Nigeria.

Federal Republic of Nigeria (1999 Constitution). Abuja: Federal Government Printers.

Freedman, L (1998) "International Security: Changing Targets; Foreign Policy, 110:48-63.

Freedman, L (2004) “The Concept of Security", in Mary Hawksworth and Maurice Kogan (Eds) Encyclopedia of Government and Politics. Vol.2 $2^{\text {nd }}$ edition. London: Routledge.

Freedman, L. (1977) U.S. Intelligence and Soviet Strategic Threat, basing stock: Macmillan.

Imobighe, T.A. (1981) “African defense and Security: An Overview, "Nigerian Forum (April).

Kajo, T. "Nigeria not ripe for State Police, Says Tsvar", Daily Sun, Thursday, June 28, P 5.

Morgenthau, H. (1948) Politics Among nations, New York: Knopf. 
Moulaye, Z (2006). Democratic Governance of Security in Mali; A sustainable Development Challenges, Abuja: Friedich Ebert stiffing.

Nnoli, (2006) National Security in Africa: A Radical New Perspective. Enugu: PACREP.

Nweke, G.A. (1985), African Security in the Nuclear Age; Enugu: Forth Dimension Pub.

Nweke, G.A. (1988) "Some Critical Remarks on the National Security Question”, Nigerian Journal of International Affairs. Vol. 12. pp. 1-7.

Oderemi (2012), “Agitation for State Police: Real Police or Private Armies? Daily Sun, July 1, P, 8

Oluwasegun, V. and Anofi, D. (2007) "Military, Police Allocated 20\%" in The Daily Nation, Friday, November, 9. Vol.2 No. 0467.

Rourke, J.T. and Boyer, M.A. (2004) International Politics on the World Stage, Brief. New York: Mc Graw-Hill.

United Nations Security Council (2002) Final Reports of Experts on the Illegal Exploitation of National Resources and Other Forms of Wealth of DR Congo.

United States of America (1967) Public Papers of the Presidents: Lyndon B. Johnson - 1966 Vol. III. Washington: USA Government Printing Office.

Wolfers, A. (1962) "National Security as an Ambiguous Symbol" in Anorld Wolfers Discord and Collaboration, Baltimore: John Hopkins Uni. Press.

Zabadi, S.I. (2005). Understanding Security and security sector Dynamics 